2. Бондаренко Я.С. Посібник для вивчення курсу «Фармакологія i фармакокінетика» // Д.: РВВ ДНУ, 2014. 36 с.

3. Грецька О.В. Індивідуальні методи в системі комплексної профілактики карієсу. СтоматологИнфо. 2014. № 2-3. С. 28-29.

4. Ніжник Г.П. Фармацевтична хімія: Підручник. 2-е вид. К.: ВСВ «Медицина». 2015. 350 с.

5 Preparation, structure and properties of pyridinium and bipyridinium hexafluoro silicates / V.O. Gelmboldt, E.V. Ganin, M.M. Botoshansky, V.Yu. Anisimov, O.V. Prodan, V.Ch. Kravtsov, M.S. Fonari // Journalof Fluorine Chemistry. 2014. V. 160, № 4. P. 57-63.

DOI https://doi.org/10.30525/978-9934-26-113-8-33

\title{
РОЗРОБКА ЕМУЛЬГЕЛЮ НА ОСНОВІ РОСЛИННОЇ СИРОВИНИ
}

\author{
Сліпченко Г. Д. \\ кандидат фармачевтичних наук, \\ дочент кафедри заводської технології ліків \\ Національний фармацевтичний університет \\ Рубан О. А. \\ доктор фармачевтичних наук, професор, \\ завідувач кафедри заводської технології ліків \\ Національний фармачевтичний університет \\ м. Харків, Украӥна
}

Проведено дослідження зі створення нового лікарського засобу (ЛЗ) для місцевого лікування ран на основі шоломниці байкальської екстракта сухого у формі емульгелю. Доцільність розробки даного ЛЗ було обгрунтовано за результатами маркетингового дослідження фармацевтичного ринку України дерматологічних препаратів 3 антимікробною, протизапальною і ранозагоювальною дією.

На основі проведених літературних досліджень нами були обрані гелеутворювальні речовини, які найчастіше використовуються при розробці засобів місцевої дії, а саме: карбомер марки «Ultrez $10 \mathrm{NF}$ », натрію альгінат та гідроксиетилцелюлоза (ГЕЦ) марки Natrosol 250 HНX. До отриманих гелів додавали як олійну фазу олію кукурудзяну в кількості $20 \%$ та емульгатор Prolipid $141^{\mathrm{TM}}$ у конценрації 3\%. 
Емульгатор сплавляли 3 олійною фазою при температурі $70 \pm 5^{\circ} \mathrm{C}$, перемішували до однорідної маси, додавали до водної фази i гомогенізували. Були досліджені органолептичні властивості отриманих зразків, визначені їх в'язкість та значення механічної стабільності (MC), які наведено в табл 1.

Як свідчать дані таблиці, досліджувані емульгелі мали однорідну консис-тенцію, світло-жовтий колір та специфічний запах. Вивчення ступеня руйнуван-ня внутрішньої структури створених емульгелів показало незначний ступінь руйнування структурної сітки гелю на основі карбомеру Ultrez $10 \mathrm{NF}$ у процесі перемішування $(\mathrm{MC}=1,03)$. На наступному етапі були проведені реологічні дослідження зразків.

\section{Таблиця 1}

Фізико-хімічні та органолептичні властивості отриманих зразків

\begin{tabular}{|c|c|c|c|c|c|}
\hline $\begin{array}{c}\text { № } \\
\text { зразка }\end{array}$ & Гелеутворювач & $\begin{array}{c}\text { Зовнішній } \\
\text { вигляд, } \\
\text { колір та запах }\end{array}$ & $\begin{array}{c}\eta(\text { (при } \\
20 \\
\text { об/хв), } \\
\text { мПа·с }\end{array}$ & $\mathrm{MC}$ & $\mathrm{pH}$ \\
\hline 1 & $\begin{array}{c}\text { Натрію альгінат } \\
1,5 \%\end{array}$ & $\begin{array}{c}\text { Гель однорідної } \\
\text { консистенції, } \\
\text { світло-жовтого } \\
\text { кольору зі } \\
\text { специфічним } \\
\text { запахом } \\
\end{array}$ & 2800 & 1,26 & $6,17 \pm 0,12$ \\
\hline 2 & ГЕЦ 1,5 \% & $\begin{array}{c}\text { Гель однорідної } \\
\text { консистенції, } \\
\text { світло-жовтого } \\
\text { кольору зі } \\
\text { специфічним } \\
\text { запахом }\end{array}$ & 6300 & 1,35 & $5,7 \pm 0,10$ \\
\hline 3 & $\begin{array}{c}\text { Ultrez } 10 \text { NF } 1,5 \\
\%\end{array}$ & $\begin{array}{c}\text { Гель однорідної } \\
\text { консистенції, } \\
\text { світло-жовтого } \\
\text { кольору зі } \\
\text { специфічним } \\
\text { запахом } \\
\end{array}$ & 8700 & 1,03 & $6,5 \pm 0,02$ \\
\hline
\end{tabular}

Кращими тиксотропними властивостями володіли зразки на основі карбомеру Ultrez 10 NF у концентрації 1,5 та $2,0 \%$. Зразок 3 концентрацією $2 \%$ відновлював свою структуру довше, що пов'язано 3 його більшою в'язкістю. Тому для подальших досліджень як гелеутворювач обрано Ultrez 10 NF у концентрації 1,5\%. 
3 метою обгрунтування вмісту олійної фази були приготовані зразки емульгелю із вмістом олії кукурудзяної 10\%, $15 \%$ та $20 \%$.

Одержані зразки являли собою гомогенні кремоподібні маси жовтуватого кольору, без візуальних ознак фазової нестабільності.

Для візуальної оцінки міжфазної взаємодії в приготовлених зразках використовували метод оптичної мікроскопії. Результати візуалізації зображено на мікрофотографіях (рис. 1). Найбільш дрібнодисперсною, а отже, і найбільш стійкою до розшарування, є емульсія з вмістом олії кукурудзяної 20\% (зразок № 3).

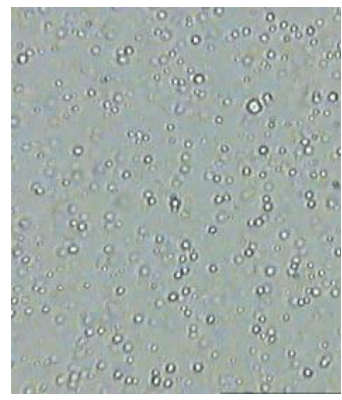

a) склад 1

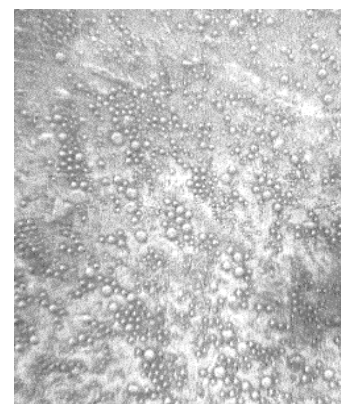

б) склад 2

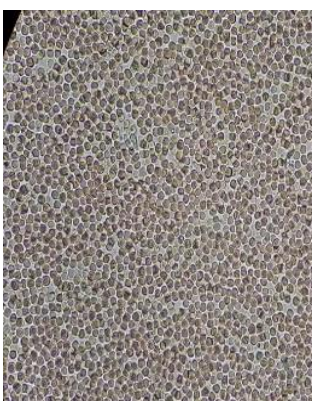

в) склад 3

Рис. 1 Мікрофотографії емульсій із різним вмістом олії кукурудзяної (збільшення 60х): а )10\%; б) 15\%; в) $20 \%$

3 метою вибора емульгатора використовували такі речовини, як полоксамер марки P188 (співполімер пропіленоксиду та етиленоксиду) фірми «BASF» (ГЛБ > 24), емульгатор Prolipid $141^{\mathrm{TM}}$ фірми Ashland (суміш лецитину, гліцерину стеарату, бегенілового, меристилового, цетилового та лаурилового спирту, пальмітинової та стеаринової кислот) (ГЛБ > 20) та емульгатор № 1 (ГЛБ - 13,4).

Раціональним емульгатором обрано Prolipid $141^{\mathrm{TM}}$ у концентрації $3 \%$, який забезпечує стійкий стан рівноваги між руйнуванням структури та іiі відновленням. Для підтвердження цього було проведено мікроскопічне дослідження ступеня дисперсності одержаних зразків [1].

Дослідження антимікробної активності зразків гелю були проведені на базі Інституту мікробіології та імунології ім. І. І. Мечникова НАМН України під керівництвом завідувачки лаб. біохімії та біотехнології к.б.н. Т. П. Осолодченко [2]. 
У результаті скринінгу установлено, що зразки володіють помірною протимікробною активністю щодо протестованих референтних штамів грампозитивних та грамнегативних мікроорганізмів, а також до клінічних ізолятів мікроорганізмів.

Фармакологічні дослідження довели протизапальну та репаративну дію запропонованого препарату у вигляді емульгелю [3].

\section{Література:}

1. Сліпченко Г. Д., Рубан О. А. Дослідження зі створення м'якого лікарського засобу з сухим екстрактом шоломниці байкальської. Фармащевтичний часопис. № 1. 2020. С. 21-27.

2. Slipchenko G. D., Osolodchenko T. P., Ruban O. A. Study of antibacterial properties of the emulgel with scutellaria baicalensis extract. Annals of Mechnikov Institute. 2019. № 4. P. 45-50.

3. Сліпченко Г. Д., Рубан О. А., Срьоменко Р. Ф., Остапець М. О. Експериментальне вивчення фармакологічної активності та токсикологічних характеристик нового гелю на основі шоломниці байкальської. Фітотерапія. Часопис. № 4. 2019. С. 50-54 